\title{
PENERAPAN PENDEKATAN PEMBELAJARAN CREAT UNTUK MENINGKATKAN KEAKTIFAN BELAJAR DAN PRESTASI BELAJAR PADA SISWA KELAS XI IPS DI SEKOLAH MENENGAH ATAS
}

Oleh:

Syamsu Ahmad Noor ${ }^{1}$

\begin{abstract}
Desain pembelajaran yang tidak optimal, serta rendahnya keaktifan belajar siswa, sangat berpengaruh terhadap hasil belajar siswa dalam pembelajaran ekonomi. Tujuan dari penelitian ini adalah untuk mengetahui apakah penerapan pembelajaran CREAT dapat meningkatkan keaktifan belajar siswa dan hasil belajar siswa. Jenis penelitian ini adalah penelitian tindakan kelas dengan pendekatan mixed method. Penelitian ini menggunakan empat metode pengumpulan data, yaitu dokumentasi, observasi, metode tes dan wawancara. Implementasi tindakan menggunakan tahapan sebagai berikut: 1) persepsi dan motivasi, 2) kegiatan inti (pembentukan kelompok, pembelajaran dengan pendekatan $C R E A T$ ). Hasil penelitian menunjukkan bahwa penerapan model pembelajaran CREAT dapat meningkatkan keaktifan dan antuasias belajar siswa. Peningkatan keaktifan belajar bisa terlihat bahwa indikator disiplin kehadiran peserta didik meningkat. Penerapan pembelajaran CREAT dapat memberikan dampak pembelajaran yang lebih bermakna dengan pembentukan karakter pada peserta didik, serta meningkatkan prestasi di bidang karya ilmiah.
\end{abstract}

Kata Kunci: Keaktifan Belajar, Pembelajaran Creat, Prestasi Belajar

\footnotetext{
${ }^{1}$ Guru Ekonomi SMA N 1 Girimarto, Kabupaten Wonogiri. Email: ahmad.noor32@gmail.com
} 


\section{PENDAHULUAN}

Peraturan Pemerintah Nomor 32 tahun 2013, pada pasal 19 ayat 1 mengamanatkan bahwa proses pembelajaran pada satuan pendidikan diselenggarakan secara interaktif, inspiratif, menyenangkan, menantang, memotivasi peserta didik untuk berpartisipasi aktif, serta memberikan ruang yang cukup bagi prakarsa, kreativitas, dan kemandirian sesuai dengan bakat, minat, dan perkembangan fisik serta psikologis peserta didik. Berdasarkan kutipan regulasi pendidikan tersebut, bahwa proses pendidikan dan pembelajaran pada satuan pendidikan manapun, secara yuridis formal dituntut harus diselenggarakan secara aktif, inovatif, kreatif, dialogis, demokratis dan dalam suasana yang mengesankan dan bermakna bagi peserta didik.

Desain kegiatan belajar mengajar yang diterapkan oleh guru dalam pembelajaran Ekonomi selalu mengalami perkembangan dalam implementasi pembelajaran yang berpusat pada siswa (student center). Hal ini sangat berpengaruh terhadap kondisi proses belajar mengajar serta keaktifan siswa di kelas. Desain pembelajaran yang belum optimal, serta keaktifan belajar peserta didik yang rendah, sangat berpengaruh terhadap hasil belajar peserta didik yang belum memuaskan dalam pembelajaran ekonomi. Terbukti dari hasil ulangan harian menunjukkan hasil belajar yang belum sesuai dengan harapan guru. Hasil Ujian Nasional juga masih menduduki peringkat yang rendah di tingkat Kabupaten. Sedangkan penghargaan di kejuaraan ilmiah juga masih sangat minim.

Dalam penelitian Riani Novitasari dengan judul, Penerapan metode pembelajaran Group Investigation dalam meningkatkan prestasi belajar Ekonomi pada siswa kelas XI SMA, mengidentifikasikan bahwa sebagian besar siswa telah mencapai ketuntasan belajar klasikal, Peningkatan prestasi belajar dinyatakan berhasil jika 75\% dari jumlah siswa tuntas belajar di atas nilai KKM 75. Hal ini menunjukkan bahwa model maupun pendekatan pemeblajaran yang dilakukan sangat berpengaryh terhadap hasil belajar siswa. 
Meskipun telah banyak penelitian tindakan kelas yang menerapkan pendekatan pembelajaran, namun dalam materi pembelajaran yang berbeda, masih diperlukan desain pembelajaran yang sesuai dengan materi pembelajaran tersebut. Masih dijumpai juga permasalahan keaktifan siswa, berkaiatan dengan karakteristik siswa yang berbeda beda di setiap daerah. Untuk itulah diperlukan sebuah pendekatan pembelajaran yang diciptakan untuk memecahkan permasalahn, permasalahan tersebut.

Pendekatan pembelajaran CREAT diharapkan mampu memecahkan permasalahan dalam pembelajaran Ekonomi di SMA. dengan karakteristik siswa yang khas, dalam hal keaktifan belajar dan hasil belajar yang memuaskan.

Tujuan dari penelitian ini adalah: untuk mengetahui apakah penerapan pembelajaran Creat dapat meningkatkan keaktifan belajar peserta didik di SMA. Serta mengetahui apakah penerapan pembelajaran Creat dapat meningkatkan hasil belajar peserta didik.

Temuan dalam penelitian ini diharapkan menghasilkan rekomendasi yang terkait pembuatan desain pembelajaran yang sesuai dengan kebutuhan. Peneliti memadukan berbagai konsep untuk menguji pendekatan Creat dalam meningkatkan keaktifan belajar dan presatsi belajar, agar bisa menjadi masukan bagi para guru dalam memecahkan masalah desain pembelajaran yang tepat.

\section{METODE PENELITIAN}

Penelitian ini merupakan penelitian tindakan kelas. dengan sampel responden yang berjumlah 30 , yang terdiri dari lakilaki 11 orang dan perempuan 19 orang. Pendekatan penelitian yang digunakan adalah mixed method. Metodologi ini dianggap tepat karena digunakan untuk mengetahui tepat atau tidaknya Penelitian ini menggunakan empat metode pengumpulan data yaitu: 1) dokumentasi, 2) observasi, 3) metode tes dan 4) wawancara. Pelaksanaan tindakan dengan menggunakan tahapan sebagai berikut: 1) apersepsi dan motivasi 2) kegiatan inti (pembentukan kelompok, pembelajaran dengan pendekatan CREAT). Intrumen yang digunakan 
dalam penelitian ini berupa intrumen tes dan non tes. Adapun intrumen yang digunakan antara lain: 1) instrumen evaluasi kognitif, 2) lembar kegiatan

\section{HASIL DAN PEMBAHASAN}

Peneliti memilih penerapan pendekatan CREAT sebagai alternatif pemecahan masalah peningkatan keaktifan peserta didik dan peningkatan hasil belajar adalah dilandasi pemikiran bahwa keberhasilan terletak pada beberapa faktor, yaitu peserta didik, guru dan fasilitas pendukung. Penerapan pendekatan CREAT merupakan buah pemikiran peneliti untuk memberdayakan peserta didik

Dalam penelitian ini, peneliti menggunakan indikator ketercapaian hasil melalui analisis kinerja peserta didik yang meliputi:

1. Keaktifan Belajar Peserta Didik

Untuk mengetahui dampak peningkatan keaktifan peserta didik, indikator yang ditetapkan meliputi: a) disiplin kehadiran; b) keaktifan bertanya; c) keaktifan menjawab pertanyaan; d) keberanian menjelaskan di depan kelas; e) ketepatan mengerjakan tugas. peserta didik, 3) lembar observasi penialain sikap peserta didik, 4) lembar observasi keaktifan peserta didik.

2. Hasil Belajar

Keberhasilan pembelajaran dalam meningkatkan hasil belajar ditunjukkan dalam indikatorindikator yang mengacu persamaanpersamaan sebagai berikut: a) Daya Serap Individu (DSI); b) Ketuntasan dan c) Belajar Klasikal (KBK)

3. Rata-rata hasil belajar.

Rata-rata hasil belajar dikatakan tuntas jika didapatkan nilai rata-rata lebih besar atau sama dengan 78 .

4. Indikator keberhasilan pelaksanaan pembelajaran ini sebagai berikut:

a. Prosentase ketuntasan belajar klasikal mencapai lebih besar atau sama dengan $75 \%$.

b. Rata-rata kelas mencapai lebih besar atau sama dengan 78 .

c. Dalam penelitian ini, peningkatan kinerja peserta didik sebagai hasil dari tindakan, merupakan hal yang diharapkan. 


\section{Peningkatan Keaktifan Belajar}

Peserta Didik

Peningkatan Keaktifan Belajar bisa dilihat pada tabel 1. Dari Tabel I di atas, terlihat bahwa indikator disiplin kehadiran peserta didik meningkat, keaktifan bertanya meningkat sebesar $33.34 \%$, keaktifan menjawab pertanyaan meningkat sebesar 50\%, keberanian menjelaskan di depan kelas meningkat 26,66\% dan kedisiplinan mengerjakan tugas meningkat $23,33 \%$. Dengan demikian penerapan pendekatan pembelajaran CREAT, dapat meningkatkan keaktifan belajar peserta didik.

\section{Hasil Belajar Peserta Didik}

Hasil belajar bisa dilihat pada tabel 2.Dari tabel 2 dapat dilihat bahwa hasil belajar kondisi awal masih kurang dari ketuntasan klasikal, karena masih $74 \%$. Dan nilai rata-rata masih di bawah KKM (78). Kemudian dicoba dengan pembelajaran CREAT. Diperoleh nilai seperti tabel 3 .

Dari tabel 3 dapat dilihat bahwa hasil belajar dengan penerapan pembelajaran CREAT mengalami peningkatan. Target ketercapaian 75\% sudah tercapai. Pembelajaran Creat memudahkan peserta didik dalam menguasai pemahaman konsep.

Tabel I. Indikator Keaktifan Belajar

\begin{tabular}{|c|c|c|c|c|c|}
\hline $\begin{array}{c}\text { Indikator } \\
\text { Keaktifan }\end{array}$ & Kondisi Awal & Prosentase & $\begin{array}{c}\text { Kondisi } \\
\text { Tindakan }\end{array}$ & Prosentase & $\begin{array}{c}\text { Kenaikan } \\
\text { Prosentase }\end{array}$ \\
\hline $\begin{array}{c}\text { Disiplin } \\
\text { kehadiran }\end{array}$ & 2 orang absen & $93,34 \%$ & Nihil & $100 \%$ & $6,66 \%$ \\
\hline $\begin{array}{c}\text { Keaktifan } \\
\text { bertanya }\end{array}$ & 2 orang & $6.66 \%$ & 12 orang & $40 \%$ & $33.34 \%$ \\
\hline $\begin{array}{c}\text { Keaktifan } \\
\text { menjawab } \\
\text { pertanyaan }\end{array}$ & 1 orang & $3,33 \%$ & 16 orang & $53,33 \%$ & $50 \%$ \\
\hline Keberanian & & & & & \\
\hline
\end{tabular}




\begin{tabular}{|c|c|c|c|c|c|}
\hline $\begin{array}{c}\text { menjelaskan di } \\
\text { depan kelas }\end{array}$ & - & $0 \%$ & 8 orang & $26,66 \%$ & $26.66 \%$ \\
\hline $\begin{array}{c}\text { Disiplin } \\
\text { mengerjakan } \\
\text { tugas }\end{array}$ & $\begin{array}{c}7 \text { org } \\
\text { terlambat } \\
\text { mengum- } \\
\text { pulkan tugas }\end{array}$ & $76,67 \%$ & $\begin{array}{c}\text { Semua tepat } \\
\text { waktu }\end{array}$ & $100 \%$ & $23,33 \%$ \\
\hline
\end{tabular}

Tabel 2. Nilai gabungan sikap (A), dan pengetahuan (B).

(komulatif $=1 \mathrm{~A}+3 \mathrm{~B} / 4$ )

\begin{tabular}{|c|c|c|c|}
\hline \multirow{2}{*}{ Nilai } & \multicolumn{2}{|c|}{ Aspek } & \multirow{2}{*}{ Hasil Belajar } \\
\cline { 2 - 3 } & Sikap & Pengetahuan & 81 \\
\hline Tertinggi & 85 & 80 & 70 \\
\hline Terendah & 69 & 70 & 76 \\
\hline Rata-rata & 77 & 76 & $74 \%$ \\
\hline Ketercapaian & \multicolumn{3}{|}{} \\
\hline Target \\
Ketercapaian
\end{tabular}

Tabel 3. Nilai gabungan sikap (A), dan pengetahuan (B).

(komulatif $=1 \mathrm{~A}+3 \mathrm{~B} / 4$ )

\begin{tabular}{|c|c|c|c|}
\hline \multirow{2}{*}{ Nilai } & \multicolumn{2}{|c|}{ Aspek } & \multirow{2}{*}{ Hasil Belajar } \\
\cline { 2 - 3 } & Sikap & Pengetahuan & 86 \\
\hline Tertinggi & 90 & 85 & 71 \\
\hline Terendah & 75 & 70 & 78 \\
\hline Rata-rata & 79 & 78 & $77 \%$ \\
\hline Ketercapaian & & $75 \%$ \\
\hline Target & & \\
Ketercapaian & & & \\
\hline
\end{tabular}


KESIMPULAN

Penerapan pembelajaran Creat dapat meningkatkan keaktifan belajar peserta didik di SMA. Penerapan pembelajaran CREAT dapat meningkatkan hasil belajar peserta didik di SMA. Penerapan pembelajaran CREAT dapat memberikan dampak pembelajaran yang lebih bermakna dengan pembentukan karakter pada peserta didik, serta meningkatkan prestasi di bidang karya ilmiah. Dalam suatu pembelajaran di kesal desain penelitian dapat diciptakan sendiri oleh guru yang mengampu di kelas tersebut,disesuaikan dengan karakteristik peserta didik serta materi yang diajarkan. Dari penelitian ini diharapkan para guru dapat lebih creatif menciptakan metode, model maupun pendekatan pembelajaran sendiri, yang kemudian berimplikasi pada munculnya penelitian baru.

\section{DAFTAR PUSTAKA}

Anni, CT. (2006). Psikologi Belajar, Semarang. UOT MKK Universitas Negeri Semarang. Azwar,(2007). Tes Prestasi, Yogyakarta: Pustaka Pelajar

Joyce, (2009). Models of Teaching, Yogyakarta : Pustaka Pelajar.

Juniati, (2012). Peningkatan Kompetensi Atom, Ion, dan Molekul melalui Pendekatan SETS pada peserta didik kelas VII G SMP SMP Negeri 3 Purworejo Semester 1 Tahun Pelajaran 2012/2013, Semarang. Jurnal Metodika Volume 3 No.9 Mei 2013.

Kemendiknas, (2008). Pendekatan, Jenis dan Metode Penelitian Pendidikan. Jakarta.

Slametto, (2003). Belajar dan Faktor-Faktor yang mempengaruhinya. Jakarta: Rineka Cipta. 
